\title{
Thermal Performance Analysis of Parabolic Trough Solar Collector Sys- tem in Climatic Conditions of Errachidia city, Morocco
}

\author{
Mohamed Hajja $\left.\right|^{\text {| }}{ }^{1}$, Amine Tilioua ${ }^{2}$, Abdellah Mellaikhafi ${ }^{2}$, Abella Bouaaddi ${ }^{1}$ \\ ${ }^{1}$ Laboratory Engineering Energy, Materials and Systems, Department of Physics, National School of Applied Sciences, Ibn Zohr University \\ Agadir, 80000, Morocco \\ ${ }^{2}$ Thermal and Applied Thermodynamics, Mechanics Energy Efficiency and Renewable Energies Laboratory, Department of Physics, \\ Faculty of Sciences and Techniques Errachidia, Moulay Ismaïl University of Meknès, B.P. 509 Boutalamine Errachidia, Meknes, 50050, \\ Morocco
}

A R T I C L E I N F O

Article history:

Received: 03 July, 2020

Accepted: 19 July, 2020

Online: 14 September, 2020

Keywords:

Parabolic Trough Collector

Absober tube

Solar Domestic Heating Water

Direct Normal Irradiation

Temperature

Modelling

\begin{abstract}
A B S T R A C T
The water heating with parabolic trough solar collectors (PTC) is a very widespread and at the same time quite promising solar technology. However, PTC presents several problems in terms of the profitability of water heating. For this reason, our study of water heating with PTC collectors consists of two main parts. In the first part, we investigate the effect of direct normal irradiation in the absorber tube using the TRNSYS software of the Errachidia city. In the second part, the study is entirely focused on the heat balance of the absorber tube in order to estimate the fluid outlet temperature. Besides, a mathematical model is developed to simulate and control the fluid outlet temperature circulating through the absorber tube of the collector. The water outlet temperature prediction was carried out by a thermal performance study of the PTC in weather conditions of Errachidia city (Morocco) using TRNSYS software and Matlab Code in the year's typical days.
\end{abstract}

\section{Introduction}

A great deal of effort has been made, especially in the last decade to improve systems for converting solar energy into heat and particularly for electricity production. Parabolic trough reflector technology is the most common and is currently used by the most powerful solar power plants in the world and improving the efficiency of these concentrators is the concern of several researchers. The PTC offers the possibility to produce electricity and hot water from solar energy. The temperature of the fluid can be raised up to $500{ }^{\circ} \mathrm{C}$. The operating principle of this technology is based on the concentration of the sun's rays on a horizontal tube, where a heat transfer fluid circulates that will be used to transport the heat to the power plant itself. The parabolic-cylindrical collector is composed of a long mirror (usually with silver or polished aluminum plating), rectangular, parabolic cylinder shape and completed by a tube with a double vacuum envelope that runs along the entire length of the focal length line. The sun's rays are reflected by the mirror to converge on the tube. The absorber tube is the essential part of the concentrator, it is often made of copper covered with a selective layer, and it is surrounded by a transparent glass envelope. The parabolic shape of the mirrors allows the sun's rays to be concentrated throughout the tube. By circulating the heat-transfer fluid in the center of this tube, the fluid is heated and conducts the heat to the container with a determined flow rate. As with any concentrating collector, parabolic troughs need to follow the sun in order to concentrate direct solar radiation. As a line concentration collector, the parabolic cylinder has a single axis tracking system. Schematic of the solar PTC system with receiver is presented in Figure 1. Several studies have been conducted by researchers to improve the energy efficiency of parabolic trough systems. Cheng et al [1] examined the temperature distribution at the outer surface of the absorber tube of a $\mathrm{CCP}$ as a function of the surface radiation flux distribution using the Monte Carlo MCRT method. The authors have combined the MCRT method and the finite volume method via the Fluent ANSYS calculation code, elaborating a multitude of simulations and taking into account the dependence of the physical properties of the heat transfer fluid (Sylitherm 800 oil) with temperature. The results obtained were compared with previous experimental data [2] and it was noticed that there was a $2 \%$ difference in the temperature

${ }^{*}$ Corresponding Author: Mohamed Hajjaj, BP 607 Boutalamine, Errachidia 52000, Morocco. Email: med.hajjaj85@gmail.com 
of the heat transfer fluid (HTF) at the absorber outlet. In addition, Kaloudiset al [3] performed a numerical study on the collector of a parabolic-cylinder concentrator system with nano heat transfer fluid, in order to simulate the SEGS LS2 type collector. The authors used four cases of boundary conditions for numerical simulation involving all heat transfer modes at the different tube interfaces.

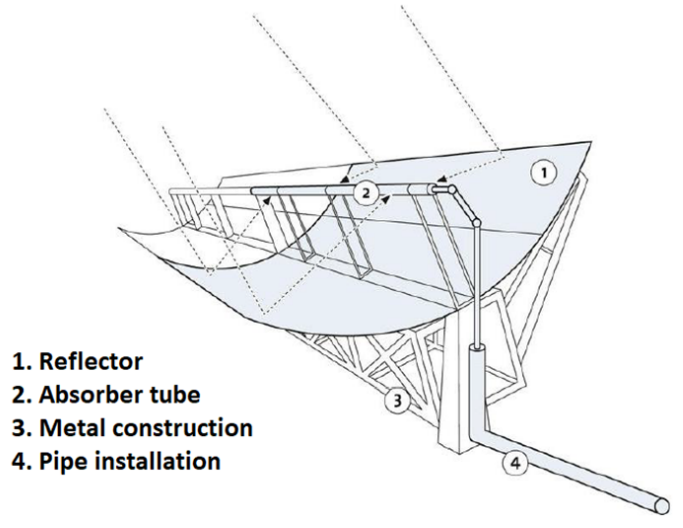

Figure 1: Schematic of the PTC system with receiver [4]

Besides, In [5], the authors have investigated the energy performance of a PTC solar in the climatic conditions of the Algerian Sahara. The authors performed a simple numerical simulation of the one-dimensional implicit finite difference method applied to the energy balance of solar collectors by dividing the absorber tube, the glass cover and the fluid in many segments. Both fluids were used, water and synthetic oil TherminolVP-1 in the simulation. However, simulation results showed that the thermal efficiency is approximately 69.73 and $72.24 \%$, which decreases at higher temperatures of synthetic oil-based fluids but increases by $2 \%$ at lower water temperatures. Bellos et al [6] have studied three different types of parabolic cylindrical collectors (vacuum tube receptor, non-vacuum tube receptor and bare tube without cover) to improve the thermal margin with the implementation (Syltherm $800 / \mathrm{Cu}$ ) in a systematic manner. The use of nanofluids improved performance in the bare tube with $7.16 \%, 4.87 \%$ for the non-evacuated receptor and $4.06 \%$ for the evacuated receptor at a flow-rate of $25 \mathrm{~L} / \mathrm{min}$. Zhao et al [7] have examinated the global performance of the PTC solar using three different tubes (one smooth and two internally finned tubes), the authors characterized the solar collector performance by energy efficiency, exergy efficiency and thermo-hydraulic efficiency. The results obtained showed that the output temperature of the solar air collectors depends on the solar irradiation, the air flow rate and the geometry parameters of the spindle fin. IPF\#2 tubes have the highest collector efficiency and air temperature, while the STube without using pin fins has the lowest values.

In Morocco, the solar plan is part of the national energy strategy which aims at quantitatively assessing the level of security of a secure and sustainable, clean, green and accessible energy provision [8]. The idea is, therefore, to study the energy efficiency of a parabolic trough solar collector and the thermal behavior of an absorber tube to improve their efficiency. The simulation is divided into two steps, the first part includes the simulation using the TRNSYS software [9], on the entire cylindro-parabolic system whose aim is to control this system and especially its operation in Saharan environment, in order to provide hot water in collective buildings [10], and taking into account the specific climatic effects in the Errachidia city (South of Morocco). In the second part, we numerically investigate using a developed Matlab code the geometrical effect of absorber tubes in order to improve the energy efficiency of a parabolic trough solar collector.

\section{Theoretical study}

\subsection{Optical performance of PTC}

\subsubsection{Concentration rate}

The concentration rate is defined as the ratio of the opening surface to the receiver surface[11, 12].

$$
C=\frac{S_{O}}{S_{r}}
$$

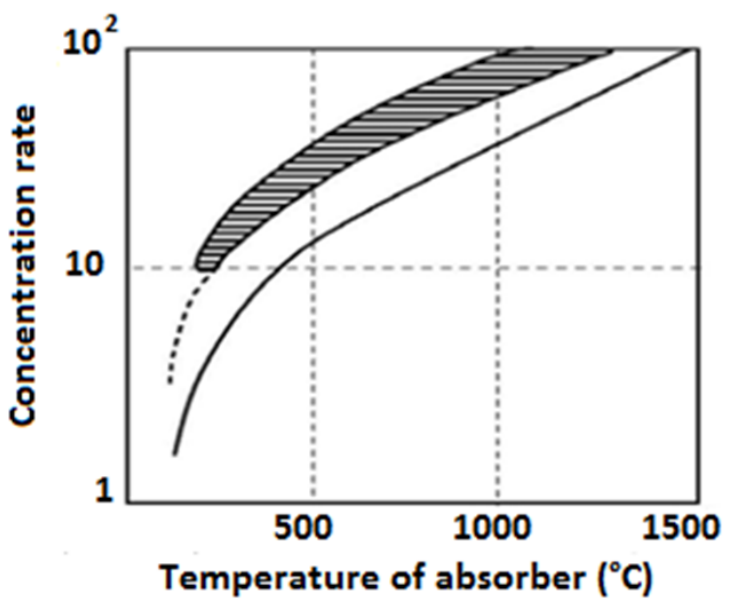

Figure 2: Concentration rate as function of the receiver temperature[11]

Figure 2 shows the variation in concentration rate as a function of absorber temperature.

- Low concentration:

$$
1<C<10 \text { involved } T_{C} \approx 150{ }^{\circ} \mathrm{C}
$$

- Average concentration:

$10<C<100$ involved $T_{C} \approx 1000{ }^{\circ} \mathrm{C}$

- High concentration:

$$
C \geqslant 100 \text { involved } T_{C} \geqslant 1000^{\circ} \mathrm{C}
$$

\subsubsection{Radiation absorption}

The radiation absorption is defined as follows [12]:

$$
E=E_{b} . \rho .(\gamma \cdot \tau) . C
$$




\subsection{Thermal performance study of PTC}

The thermal performance of PTC can be determined from different methods. The power received of PTC $\left(Q_{u}\right)$ is determined from the quantities $\left(F_{R}\right)$ and $\left(U_{L}\right)[12]$.

\subsubsection{Overall heat loss factor $U_{L}$ (covered tube)}

In the event that the tube receiver is covered by a glass selective surface $\left(S_{C}\right)$, the irradiation coefficient in the glass to absorber region is dissimilar from the irradiation coefficient in the absorber to glass region, this coefficient is usually negligible [10]. The coefficient of heat loss is expressed by relationship:

$$
\begin{gathered}
F^{\prime}=\frac{\frac{1}{U_{L}}}{\frac{1}{U_{L}}+\frac{D_{e}}{h_{f i} D_{i}\left(\frac{D_{e}}{2 \lambda} \ln \frac{D_{e}}{D_{i}}\right)}+\frac{1}{U_{L}}} \\
F_{R}=\frac{m_{f} \cdot C_{p}}{S_{r} \cdot U_{L}} \cdot\left[1-\mathrm{e}^{\left.\left(\frac{S_{r} \cdot U_{L} \cdot F^{\prime}}{m_{f} \cdot C_{p}}\right)\right]}\right. \\
U_{L}=\left[\frac{S_{r}}{\left(h_{v}+h_{r, c-a}\right) \cdot S_{r}}+\frac{1}{h_{r, a-c}}\right] \\
h_{r, c-a}=\frac{\sigma\left(T_{r}^{2}-T_{c}^{2}\right) \cdot\left(T_{r}-T_{c}\right)}{\frac{1-\varepsilon_{r}}{\varepsilon_{r}}+\frac{1}{F_{r c}}+\frac{\left(1-\varepsilon_{c}\right) \cdot S_{r}}{\varepsilon_{c} \cdot S_{c}}} \\
h_{r, a-c}=4 \cdot \sigma \cdot \varepsilon \cdot \bar{T}^{3}
\end{gathered}
$$

\subsubsection{Useful heat $\left(Q_{u}\right)$}

The useful heat is determined from the power recovered by the PTC at the focal line and it is expressed by the following relationship:

$$
Q_{U}=F_{R} \cdot\left[E . \rho . \tau \cdot \alpha \cdot \gamma \cdot S_{o}-U_{L} \cdot S_{r}\left(T_{\text {out }}-T_{\text {inl }}\right)\right]
$$

\subsubsection{The outlet temperature $T_{\text {out }}$ of HTF}

The output temperature of HTF is determined from the following equation [13]:

$$
T_{\text {out }}=T_{\text {inl }}+\frac{Q_{U}}{m_{f} \cdot C_{p}}
$$

\subsubsection{Solar concentrator efficiency $\eta$}

The efficiency of the PTC is given by the following relationship [14].

$$
\eta=\frac{Q_{U}}{E \cdot \gamma \cdot S_{o}}
$$

\section{Numerical simulation}

\subsection{TRNSYS model}

To evaluate the thermal efficiency of a solar PTC, we used the TRNSYS software. It allows users to specify the system components and to connect these components together. Each component (type) contains input and output parameters.
In the present study, a new numerical model is developed using the Matlab language to simulate the temperature evolution in the fluid, absorber and glass cover. Concerning the simulation by TRNSYS software, we used the different components such as a parabolic cylindrical collector (type 536) and a pump (type 3d). Other components used: weather (type 109), regulation (type 2b) ON/OFF differential controller, storage tank (type 4c) and online plotter (type 65a). The schematic of the TRNSYS model of the PTC system takes into account water as HTF in the weather conditions of Errachidia city, it is presented in Figure 3

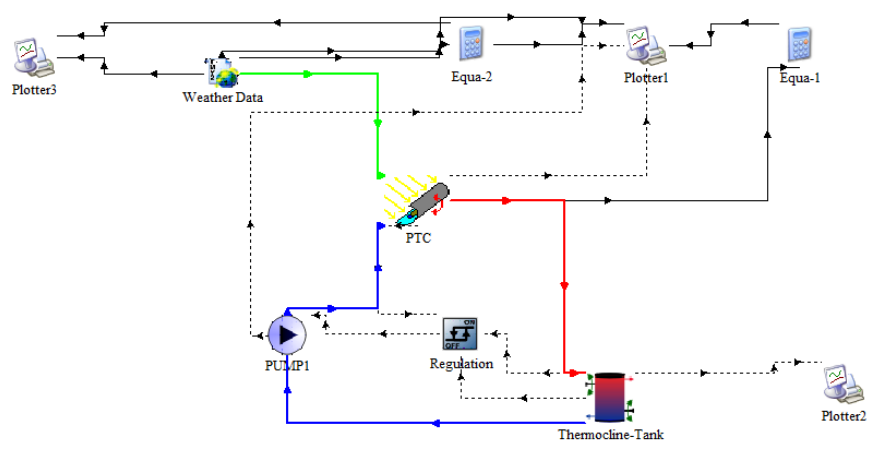

Figure 3: TRNSYS model of a solar PTC with Thermocline- Tank

\subsection{Weather data of Errachidia city}

Morocco's energy efficiency agency has proposed a new classification of climatic zones, each having different meteorological properties. In addition, the wind speed, ambient temperature, and total radiation on the inclined surface of the city under study are generated by the METEONORM software. According to this study's aims, which focuses on the thermal efficiency of a PTC tube for the Errachidia site. Geographical localization of Errachidia city (semi-arid climate) offers the ideal climatic conditions such as intense sunshine all year round, low humidity and precipitation. The ambient temperature variation all year round in the selected zone is shown in Figure 4 . Besides, the estimation of the direct normal irradiation (DNI) throughout the year is shown in Figure 5 . The evolution of the annual inlet and outlet temperature of the water is illustrated in Figure 6

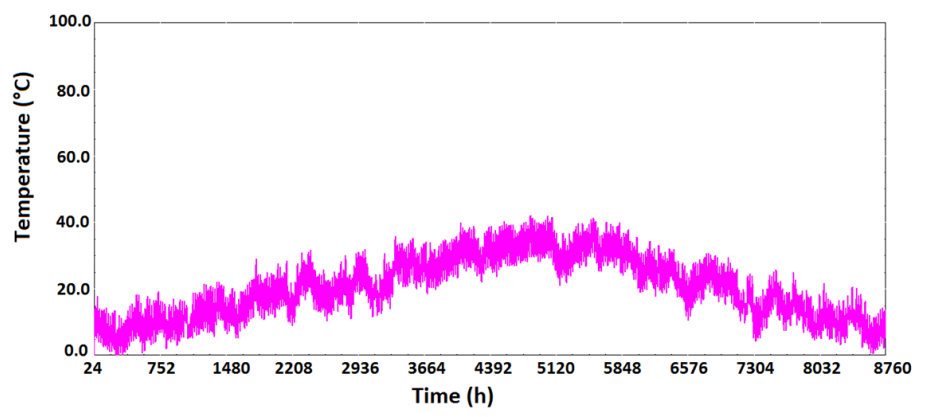

Figure 4: Ambient temperature evolution during one year at the Errachidia site 


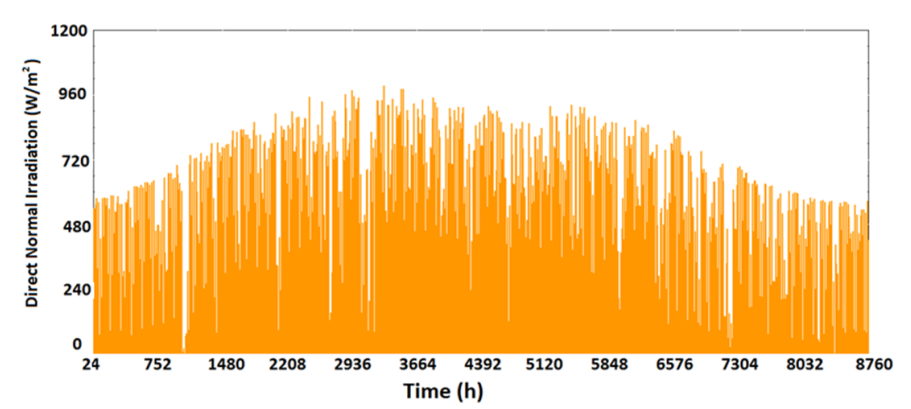

Figure 5: Annual direct normal irradiation in Errachidia city

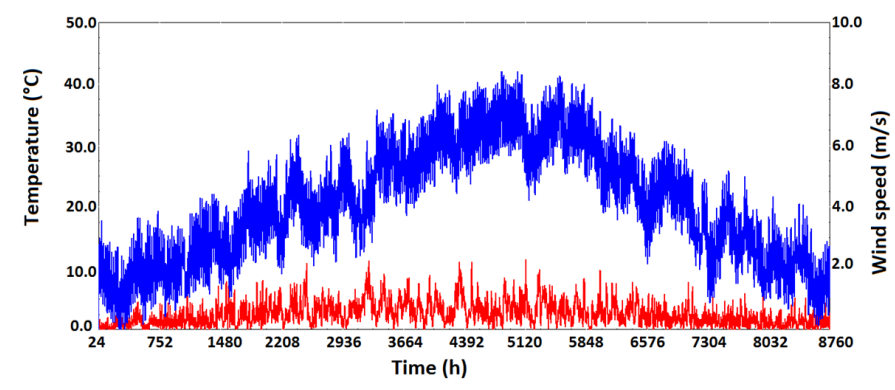

Figure 6: Variation of water inlet and outlet temperature for one year at Errachidia city

\section{Results and discussion}

The estimation of the amount solar radiation captured by the PTC is based on the method employed by [15]. For modelling the thermal behavior of PTC components in transient regime, we have taken into account the following assumptions :

- The sky is assumed to be a blackbody;

- Under climatic conditions, the physical properties of the glass and the absorber are supposed constant;

- Fluid velocity is supposed to be constant;

- The wind speed is $3.75 \mathrm{~m} / \mathrm{s}$;

- The physical properties of the fluid in the absorber are assumed to be temperature dependent;

- The air enclosed between the absorber and the glass is stagnant and transparent.

\subsection{Geometrical and optical parameters of PTC}

The main element of PTC system which allows receiving incident solar radiation is the absorber, also it allows to convert radiation in the form of heat and transmit it to the HTF. The incident solar radiation is not entirely absorbed and transmitted to the HTF, but part is dissipated as heat loss between the absorber and the cover glass. Figure 7 illustrates heat transfer of the absorber used, taking into consideration the different shares of energy, which were collected by the fluid and lost to the environment. a)

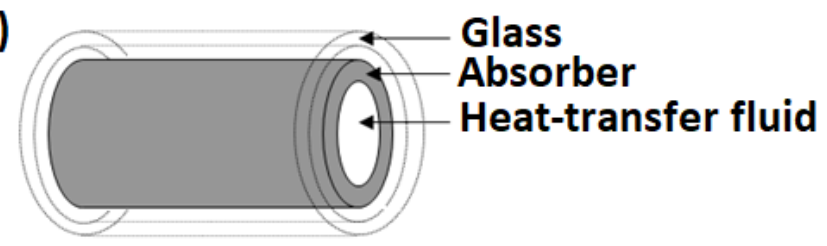

b)

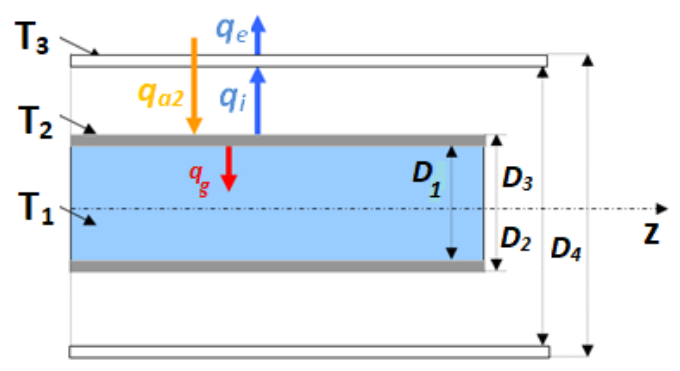

Figure 7: Thermal exchanges between the absorber tube and the other components of PTC

Tables 1 and 2 present the geometric and optical properties of the components of our PTC system. The physical properties of HTF (water) are shown in Table 3. The water temperature and the PTC components calculated from the energy balance [16], for the typical days of the year and for a HTF mass flow rate value of $0.0083 \mathrm{~kg} / \mathrm{s}$.

Table 1: Geometrical characteristics of the PTC elements

\begin{tabular}{|l|l|}
\hline Geometric characteristics & Value \\
\hline External diameter of the absorber, $D_{e}$ & $1.4 \mathrm{~cm}$ \\
\hline Internal diameter of the glass cover, $D_{(c, i)}$ & $4.2 \mathrm{~cm}$ \\
\hline External diameter of the glass cover, $D_{(c, e)}$ & $4.35 \mathrm{~cm}$ \\
\hline Effective width of the mirror, $W_{\text {eff }}$ & $1 \mathrm{~m}$ \\
\hline Element length, $\Delta \mathrm{z}$ & $0.1 \mathrm{~m}$ \\
\hline Collector absorber tube length, $L_{\text {tube }}$ & $2 \mathrm{~m}$ \\
\hline Focal distance & $0.235 \mathrm{~m}$ \\
\hline
\end{tabular}

Table 2: Optical properties of materials used

\begin{tabular}{|l|l|}
\hline Properties & Value \\
\hline Absorption coefficient of the absorber tube, $\alpha$ & 0.8 \\
\hline Glass transmission coefficient, $\tau$ & 0.8 \\
\hline Reflectance of the mirror surface, $\rho_{m}$ & 0.85 \\
\hline Emissivity of the absorber tube, $\varepsilon_{r}$ & 0.12 \\
\hline Emissivity of the glass cover tube,$\varepsilon_{c}$ & 0.9 \\
\hline
\end{tabular}

The thermal modelling of the absorber receiver of PTC is done by a calculation and programming procedure under Matlab by solving the energy balance equation. For this purpose, we have developed a calculation program to simulate the fluid temperature at the absorber outlet. The thermal model takes into account all heat transfers: convection in the receiver pipe, in the gap between the absorber and the glass cover, on the one hand, and between the glass cover and the ambient air, on the other hand. The thermal balance equation between the absorber and the HTF can be written : 


$$
\pi \rho_{1} C_{1} D_{1} \frac{\partial T_{1}}{\partial t}(z, t)=-\rho_{1} C_{1} \phi \frac{\partial T_{1}}{\partial z}(z, t)+q_{g}(z, t)
$$

The initial conditions and limits are given by following relationships:

$$
T_{1}(z, 0)=T_{a m b}(0)
$$

$$
T_{1}(0, t)=T_{e}(t)
$$

where $T_{e}$ is the inlet temperature and $T_{a m b}$ is the ambient temperature.

Table 3: Properties of heat fluid (water)

\begin{tabular}{|l|l|}
\hline Properties & Value \\
\hline Heat capacity, $C_{f}$ & $4180 \mathrm{~kJ} \cdot \mathrm{kg}^{-1} \cdot \mathrm{K}^{-1}$ \\
\hline Volume flow rate, $D_{f}$ & $30 \mathrm{l} / \mathrm{h}$ \\
\hline
\end{tabular}

Table 4: Comparison of parameter effects on PTC in the present study with other similar works.

\begin{tabular}{|c|c|c|c|}
\hline Dimension of PTC & Mass flow rate $\mathbf{K g} / \mathbf{s}$ & Temperature of water & References \\
\hline $1 \mathrm{~m} \times 2 \mathrm{~m}$ & 0.0083 & $149{ }^{\circ} \mathrm{C}$ & Present study \\
\hline $1.25 \mathrm{~m} \times 0.8 \mathrm{~m}$ & $0.0117-0.0167$ & $36.5^{\circ} \mathrm{C}$ & {$[16]$} \\
\hline $1.49 \mathrm{~m} \times 1.49 \mathrm{~m}$ & 0.00111 & $104{ }^{\circ} \mathrm{C}$ & {$[17]$} \\
\hline $1.2 \mathrm{~m} \times 1.5 \mathrm{~m}$ & 0.0017 & $65{ }^{\circ} \mathrm{C}$ & {$[18]$} \\
\hline $1.82 \mathrm{~m} \times 1.03 \mathrm{~m}$ & 0.00111 & $50{ }^{\circ} \mathrm{C}$ & {$[19]$} \\
\hline $6 \mathrm{~m} \times 2.3 \mathrm{~m}$ & 0.55 & $165^{\circ} \mathrm{C}$ & {$[20]$} \\
\hline $7.8 \mathrm{~m} \times 5 \mathrm{~m}$ & 0.345 & $47.24{ }^{\circ} \mathrm{C}$ & {$[21]$} \\
\hline
\end{tabular}

In order to produce hot water $90^{\circ} \mathrm{C}$, for domestic and industrial applications. We have choose the right mass flow and the good PTC dimensions. Table 4 presents a comparison of parameter effects on PTC in the present study with other similar works. We noticed that when the mass flow rate and the opening radius of the collector increases the outlet temperature of the hot water rises. To produce a sufficient quantity of hot water, it is necessary to select parabolic cylindrical collector dimensions in relation to the outlet temperature of the water and the mass flow rate (Table 5).

Table 5: Hot water production in $90^{\circ} \mathrm{C}$ for different theoretical cases [22]

\begin{tabular}{|l|l|l|}
\hline Dimension of PTC & Mass flow rate Kg/s & Quantity of hot water (L/day) \\
\hline $1.6 \mathrm{~m} \times 1.8 \mathrm{~m}$ & 0.0074 & 133.2 \\
\hline $1.6 \mathrm{~m} \times 3 \mathrm{~m}$ & 0.0123 & 221.4 \\
\hline $1.6 \mathrm{~m} \times 6 \mathrm{~m}$ & 0.0250 & 450.0 \\
\hline $1.6 \mathrm{~m} \times 10 \mathrm{~m}$ & 0.0411 & 739.8 \\
\hline $1.6 \mathrm{~m} \times 15 \mathrm{~m}$ & 0.0633 & 1139.4 \\
\hline
\end{tabular}
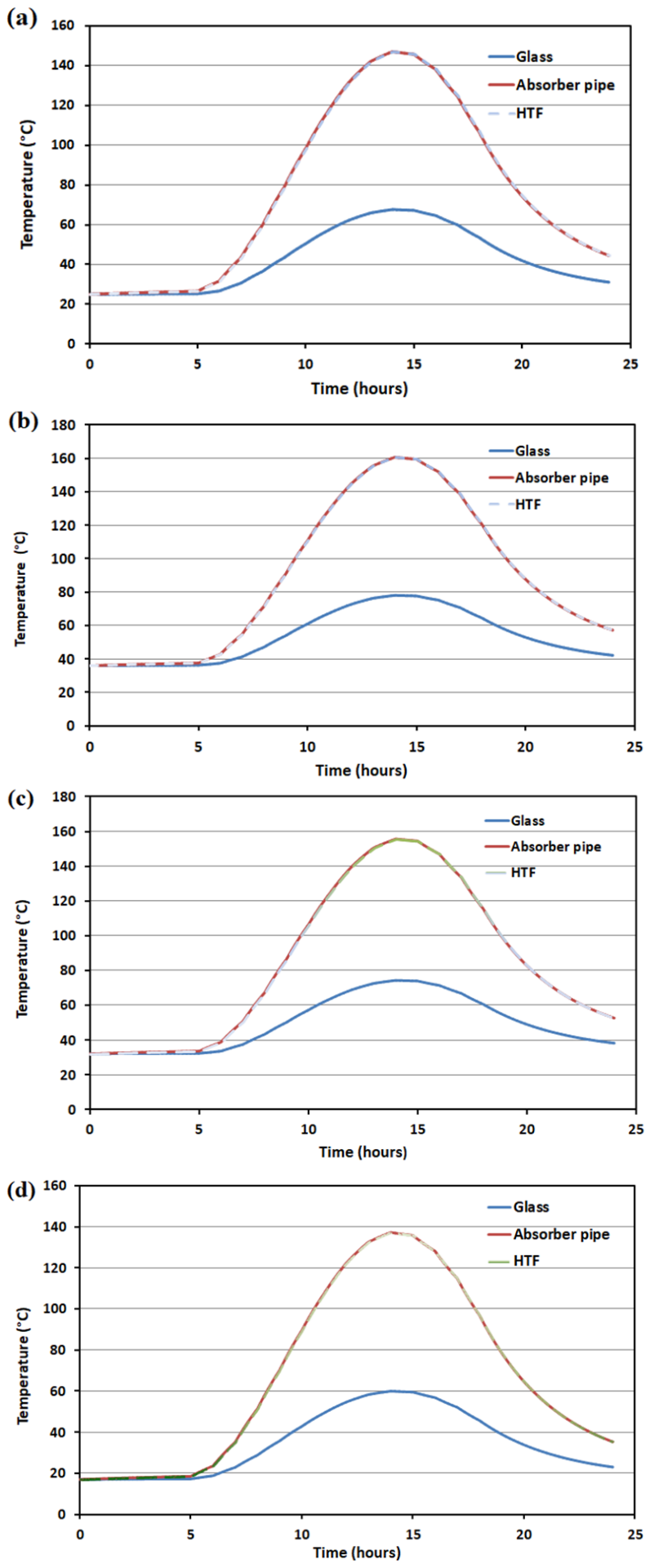

Figure 8: Outlet temperature evolution of fluid, absorber and glass for; (a) March 21, (b) June 21, (c) September 21 and (d) December 21

\subsection{Temperature outlet evolution in typical days of year}

Figure 8 shows the temperature evolution of the fluid, the absorber and the glass cover versus the time from March 21, June 21, September 21 and December 21, 2019 for the concentrator whose geometric properties are given in Table 1 . We observed that the temperature variation depends on the climatic conditions of Errachidia, particu- 
larly on the incident solar energy.
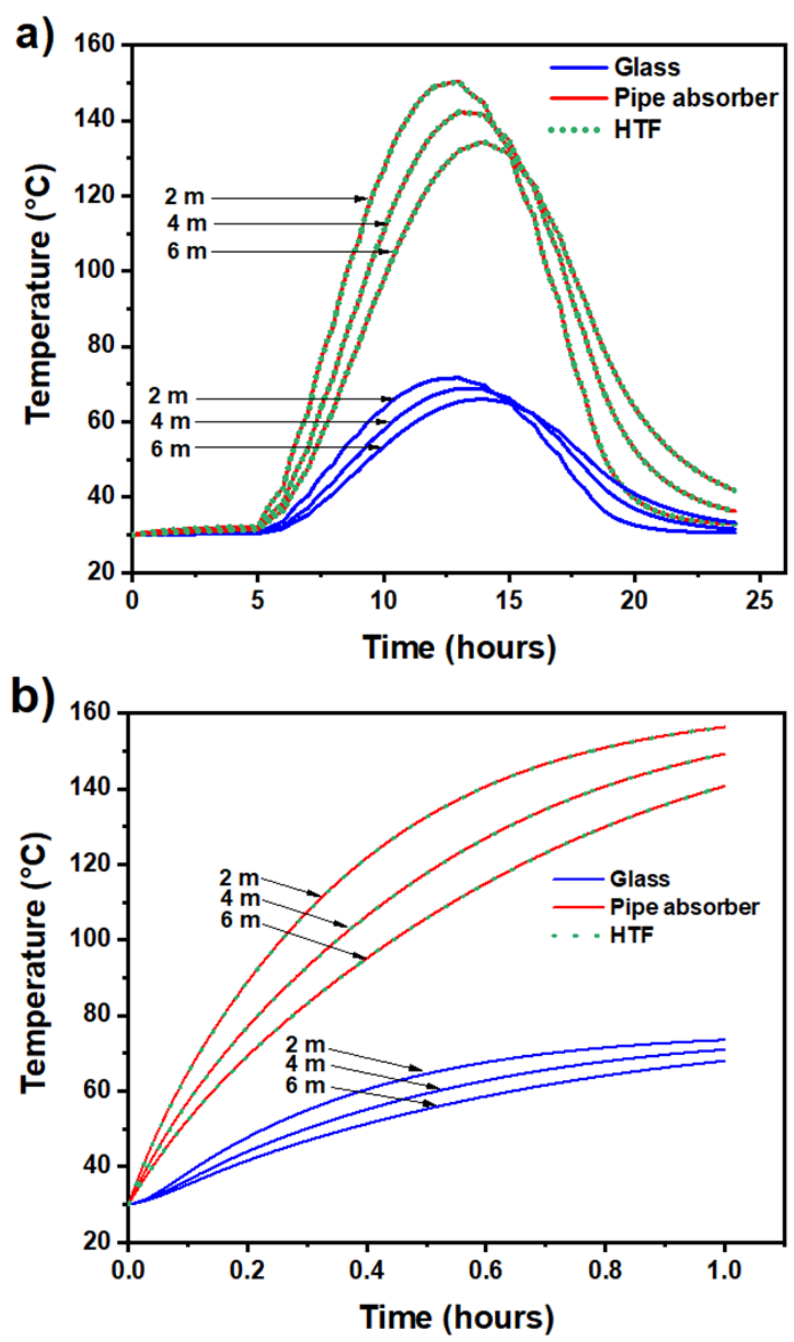

Figure 9: (a) Outlet temperature evolution of the glass, absorber and HTF for; $2 \mathrm{~m}, 4$ $\mathrm{m}$ and $6 \mathrm{~m}$ of the length tube, (b) PTC temperature - stagnation conditions.

\subsection{Absorber tube length effect}

The thermal performance of PTC and the water heating requirements depend on the geometric properties of PTC solar. In the modeling we have chosen 3 different absorber lengths $2 \mathrm{~m}, 4 \mathrm{~m}$ and $6 \mathrm{~m}$, respectively. Excluding stagnation, we observe that the risk of overheating at the PTC level does not exist, the temperature of the absorber tube stays below $70^{\circ} \mathrm{C}$ using water as HTF. The daily variation of the fluid temperature, the absorber tube and the glass cover as a function of time is illustrated in Figure $9 \mathrm{~g}$. We noticed that when the receiver pipe length is small the efficiency of the system increases and the temperature of the absorber also increase. We observed that, in theory, the stagnation of the temperature of the absorber and fluid exceeds $158^{\circ} \mathrm{C}$ of water as HTF. The risk of deterioration of the system in the case of water HTF is important. We also observed that when the absorber tube length is small the temperature of the absorber also increases (Figure $9 \mathrm{p}$ ).

\subsection{Absorber tube thickness effect}

Figure 10 shows the thickness effect of the receiver pipe on the fluid daily temperature, the receiver pipe and the glass cover versus of time for $1.5 \mathrm{~mm}, 2.5 \mathrm{~mm}$ and $3.5 \mathrm{~mm}$ respectively, for the concentrator whose geometric properties are given in Table 1 . We observe that the thickness of the absorber has a small impact on the fluid temperature evolution and stagnation of the temperature compared to the tube length.
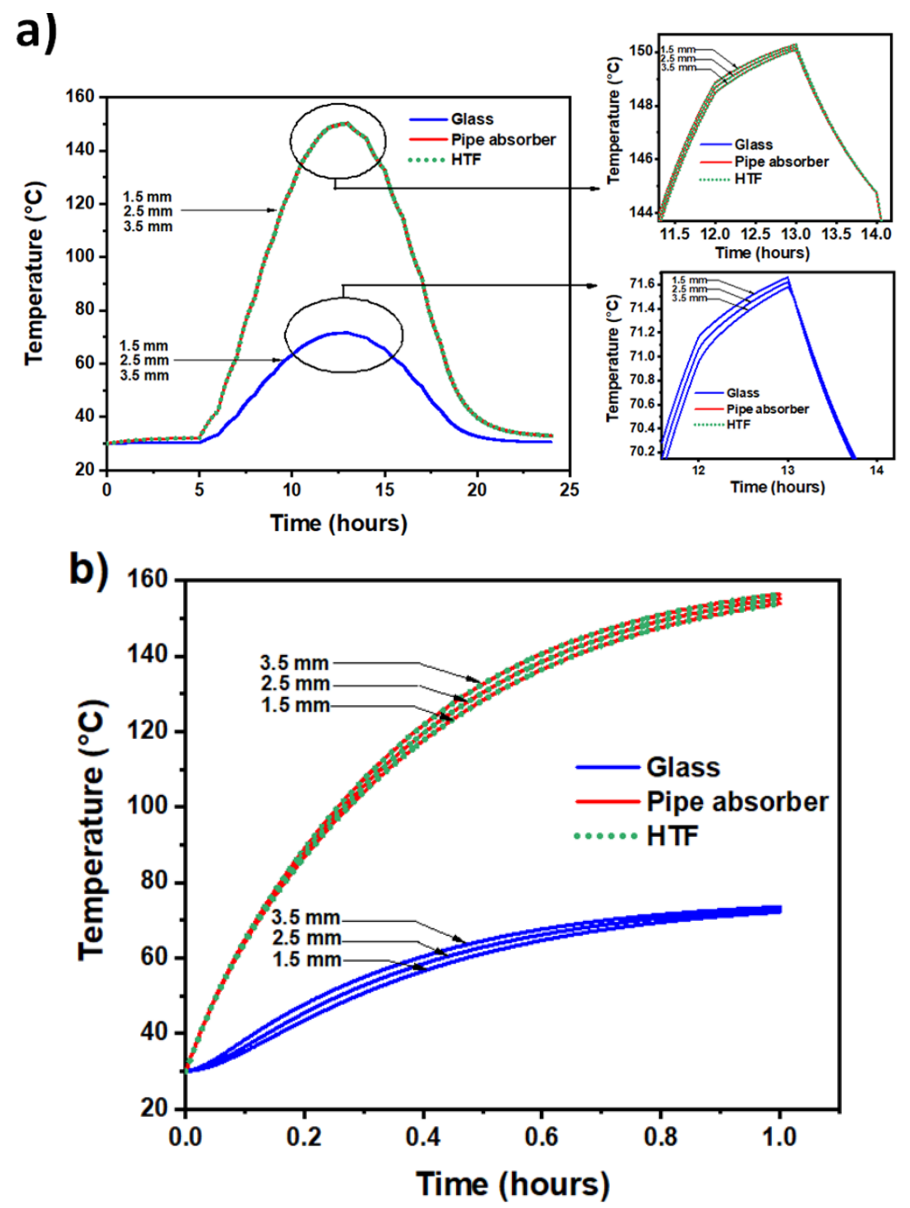

Figure 10: (a) Outlet temperature evolution of HTF, absorber and glass cover for different absorber tube thickness $1.5 \mathrm{~mm}, 2.5 \mathrm{~mm}$ and $3.5 \mathrm{~mm}$; (b) PTC temperature stagnation conditions.

\section{Conclusions}

In this paper, the study of the water heating circulating in an absorber tube of a solar PTC is investigated. The heating process modeling of the fluid is performed. To verify the temperature of fluid, absorber and glass cover, a mathematical model is elaborated from the heat exchanges of the glass tube with the environment. The geometrical dimensions of the parabolic-cylindrical collector have been taken into account in the modeling. The results obtained in this study showed that there was a significant temperature difference between the inlet and the outlet of PTC for the test days considered. Excluding stagnation, the absorber tube length effect on the fluid temperature evolution was observed. However, the absorber tube thickness effect is very small on the temperature evolution. This 
investigation offers multiple perspectives on the use and analysis of parabolic-cylindrical collector behavior such as the optical performance evaluation of the system or to test other heat transfer fluids. Finally, an economic study can be envisaged to evaluate the cost-effectiveness of the system.

\section{Nomenclature}

$\begin{array}{ll}T_{a} & \text { Ambient temperature }\left({ }^{\circ} \mathrm{C}\right) \\ T_{r} & \text { Absorber temperature } \\ \bar{T} & \text { Average irradiation temperature } \\ T_{C} & \text { Concentration temperature } \\ T_{c} & \text { Cover temperature (glass tube) } \\ T_{1} & \text { Heat transfer fluid temperature } \\ C_{p} & \text { Calorific power } \\ C_{1} & \text { Heat-transfer fluid specific heat } \\ D_{1} & \text { Internal diameter of the absorber } \\ E_{p} & \text { Incident radiation on the map opening } \\ E & \text { Incident solar radiation }\left(\mathrm{W} / \mathrm{m}^{2}\right) \\ T_{i n l} & \text { Fluid inlet temperature } \\ T_{o u t} & \text { Fluid outlet temperature } \\ F_{r c} & \text { Form factor between the receiver and the cover, } \\ & \text { which is equal to } 1 \\ h_{f i} & \text { Heat transfer coefficient at inside the absorber }\left(\mathrm{W} /\left(\mathrm{m}^{2} .{ }^{\circ} \mathrm{C}\right)\right. \\ m_{f} & \text { Mass flow } \\ S_{o} & \text { PTC opening area } \\ S_{r} & \text { Receiver surface }\left(\mathrm{m}^{2}\right) \\ D_{e}, D_{i} & \text { Outside and inside diameter of the absorber } \\ q_{g} & \text { Amount of the energy gained by the heat transfer fluid }\end{array}$

\section{Greek Symbols}

$\gamma \quad$ Optical collector factor

$\varepsilon_{r} \quad$ Emissivity of the surface of the absorber

$\lambda \quad$ Thermal conductivity $\left(\mathrm{W} /\left(\mathrm{m} .{ }^{\circ} \mathrm{C}\right)\right)$

$\tau \quad$ Transmission factor

$\rho \quad$ Reflection factor of the concentrator mirror

$\phi \quad$ Heat transfer fluid mass flow rate

$\rho_{1} \quad$ Heat transfer fluid density

$\varepsilon_{c} \quad$ Glass emissivity of the cover

$\tau \alpha \quad$ Transmission-absorption coefficient

\section{Physical constants \\ $\sigma$ Stefan-Boltzmann Constant $\left(5.667 .10^{-8} \mathrm{~W} / \mathrm{m}^{2} \mathrm{~K}^{4}\right)$}

Conflict of Interest The authors declare no conflict of interest.

\section{References}

[1] Z.D. Cheng, Y.L. He, J. Xiao, Y.B. Tao, R.J. Xu, "Three-dimensional numerical study of heat transfer characteristics in the receiver tube of parabolic trough solar collector", International Communications in Heat and Mass Transfer 37, 782-787, 2010.

[2] V.E. Dudley, G.J. Kolb, A.R. Mahoney, T.R. Mancini, C.W. Matthews, M. Sloan, D. Kearney, “ Test results: SEGS LS-2 solar collector”, Sandia National Laboratories, Albuquerque, 1994.DOI: 10.2172/70756

[3] E. Kaloudis, E. Papanicolaou, V. Belessiotis, "Numerical simulations of a parabolic trough solar collector with nanofluid using a two-phase model." Renewable Energy 97, 218-229, 2016.https://doi.org/10.1016/j.renene.2016.05.046

[4] P. Hubert Wagner, "Thermodynamic simulation of solar thermal power stations with liquid salt as heat transfer fluid", Ph.D Thesis Technical University of Munich, 2012.

[5] Y. Marif, H. Benmoussa, H. Bouguettaia, M. M. Belhadj, M. Zerrouki, "Numerical simulation of solar parabolic trough collector performance in the Algeria Saharan region”, Energy Convers. Manage. 85, 521-529, 2014. https://doi.org/10.1016/j.enconman.2014.06.002.

[6] E. Bellos, C. Tzivanidis, Z. Said, "A systematic parametric thermal analysis of nanofluid-based parabolic trough solar collectors", Sustainable Energy Technologies and Assessments, 39, 100714, 2020. https://doi.org/10.1016/j.seta.2020.100714

[7] Z. Zhao, F. Bai, X. Zhang, Z. Wang, "Experimental study of pin finned receiver tubes for a parabolic trough solar air collector ", Solar Energy, 207, 91-102, 2020.

[8] S. Zafar, Africa, Renewable Energy, Solar Energy, Wind Energy, 2019. https://www.ecomena.org/

[9] M. Hajjaj, A. Mellaikhafi, A. Tilioua, C. Messaoudi, A. Bouaaddi, Numerical Investigation and Control The Thermal Storage System in A Single-Tank for CSP Plants,International Journal of Advance Science and Technology, 29, 10s, 8378-8389, 2020. http://sersc.org/journals/index.php/IJAST/article/view/24294

[10] Z. D. Cheng, Y. L. He, J. Xiao, Y. B. Tao, and R. J. Xu, "Three-dimensional numerical study of heat transfer characteristics in the receiver tube of parabolic trough solar collector.” Int. Commun. Heat Mass Transf., 39(7), 782-787, 2010. https://doi.org/10.1016/j.icheatmasstransfer.2010.05.002

[11] M. Hajjaj, A. Bouaaddi, A. Mellaikhafi, A. Tilioua, C. Messaoudi, "Simulation of the water outlet temperature in a solar Parabolic Trough Collector in the Errachidia site " in 2020IEEE 1st International Conference (IRASET), Meknes, Morocco, 2020. DOI: 10.1109/IRASET48871.2020.9092323.

[12] J.A. Duffie and W.A. Beckman, Solar Engineering of Thermal Processes, 2nd Edition, John Wiley \& Sons Inc, 1991.

[13] W. Chekirou, N. Boukheit, T. Kerbache, "Analyse Thermique pour l'Absorbeur d'un Concentrateur Solaire Cylindro Parabolique”, 12ème Journées Internationales de Thermique, 61-64, Morocco, 2005.

[14] M. Li and L.L. Wang, "Investigation of Evacuated Tube Heated by Solar Trough Concentrating System”, Energy Convers. Manage., 47, 3591-3601, 2006. https://doi.org/10.1016/j.enconman.2006.03.003

[15] ASHRAE Handbook, Fenestration Fundamentals, USA, 2001.

[16] A. Valan Arasu and T. Sornakumar, "Performance characteristics of Parabolic Trough Solar Collector system for hot water generation", International Energy Journal, 7, 137-145, 2006. DOI: 10.2298/TSCI0602167V

[17] M. Rizwan, Md. A. R. Junaidi, M. Suleman and M. A. Hussain, "Experimental verification and analysis of Solar Parabolic Collector for water distillation”, International Journal of Engineering Research, 3, 588-593, 2014. DOI: 10.17950/ijer/v3s10/1008

[18] M. G. Tayade, R. E. Thombre and S. Dutt, "Performance evaluation of Solar Parabolic Trough", International Journal of Scientific and Research Publications, 5, 1-5, 2015.

[19] K. H. Bhujangrao, "Design and development of prototype cylindrical parabolic solar collector for water heating application", Journal of Renewable Energy Development, 5, 49-55, 2016. DOI: 10.14710/ijred.5.1.49-55

[20] M. Qu, D. H. Archer and S. V. Masson, "A linear parabolic trough solar collector performance model", Renewable Energy Resources and a Greener Future, VIII-3-3, 2006. DOI: 10.1115/ES2007-36052

[21] D. Sauceda, N. Velazquez, O. Garcia-Valladares and R. Beltran, "Numerical simulation and design of a parabolic trough solar collector used as a direct generator in a solarGAX cooling cycle", J. Mech. Sci. Technol., 25, 1399-1408, 2011. https://doi.org/10.1007/s12206-011-0326-y

[22] M. E. Soudani, K. E. Aiadi, D. Bechki, "Water heating by Parabolic Trough Collector with storage in the Ouargla region of Algerian Sahara", Materials Today: Proceedings, 24, 137-139, 2020. https://doi.org/10.1016/j.matpr.2019.07.707 